\title{
Subconjunctival suspension of RU486 lowers intraocular pressure in normal rabbits
}

\author{
SHIGEO TSUKAHARA,' TAKAYA SASAKI,' CALBERT I PHILLIPS, ${ }^{2}$ AND \\ SHEILA M GORE
}

\begin{abstract}
From the 'Department of Ophthalmology, Yamanashi Medical College, Tamaho, Yamanashi, Japan; the ${ }^{2}$ Department of Ophthalmology, University of Edinburgh and Princess Alexandra Eye Pavilion, Chalmers Street, Edinburgh EH3 9HA; and the ${ }^{3}$ Medical Research Council Biostatistics Unit, MRC Centre, Hills Road, Cambridge
\end{abstract}

SUMMARY RU486 is both a progesterone blocker and a corticosteroid blocker (peripheral). Subconjunctival injections of $0.2 \mathrm{ml}$ of a $1 \%$ suspension of RU486 powder $(2 \mathrm{mg})$ were given twice weekly to one eye chosen at random of 12 rabbits. The fellow eye received the same volume, $0.2 \mathrm{ml}$, of vehicle (normal saline) only. Ocular tension was measured twice daily for six days per week by an Alcon pneumatonograph, the tonometrist(s) being unaware of which eyes were treated and which untreated. A small but significant reduction in intraocular pressure, about $0.7 \mathrm{mmHg}$, occurred in treated eyes. No intereye difference in the ocular hypertensive response to intraperitoneal injections of distilled water $(50 \mathrm{ml} / \mathrm{kg})$ was found. Clinical trials are planned in which a larger fall is expected because the trabecular meshwork in patients with open-angle glaucoma or ocular hypertension is presumably more affected by (normal) tissue levels of corticosteroid.

It is well documented that corticosteroid eye drops will cause a rise of intraocular pressure (IOP), especially in patients with open-angle glaucoma or with a hereditary predisposition to that disease. ${ }^{1-8}$ The trabecular meshwork is presumably hypersusceptible to corticosteroids in patients who show a very high ocular hypertensive response. The appearance of a new drug, RU486, with peripheral corticosteroid blocking as well as progesterone blocking properties allowed preliminary rabbit experiments to test the hypothesis that such a drug would be useful in open-angle glaucoma. A series of 12 rabbits treated with a $1 \%$ suspension of eye drops in one eye chosen at random showed a small fall in pressure when compared with the fellow vehicle treated eye."

RU486 has the disadvantage, at least from the point of view of treatment of the eye, of extreme insolubility in water, though it is soluble in fat and fat solvents. It seemed likely that greater intraocular penetration, and therefore a more powerful ocular hypotensive effect, could be achieved by subconjunctival injection, which is the subject of the present report.

Correspondence to Professor C I Phillips, Eye Pavilion, Chalmers Street, Edinburgh EH3 9HA.
The effect on IOP is probably due to an improved outflow of aqueous humour as judged by fluorescein decay studies also in rabbits. ${ }^{10}$ That in turn is presumed to be due to a peripheral blocking effect on the normal tissue level of corticosteroid in the outflow channels. The effect may, however, be the result of the drug's peripheral progesterone blocking effect, which also accounts for its powerful contraceptive (abortifacient) properties."

\section{Material and methods}

Six New Zealand black and white and six albino rabbits (A to $L$ ) were allowed to settle down in the animal house for one week before the study began. After that, tonometry was done twice daily at about 0830 and $1700 \mathrm{~h}$ for one week without treatment (runin week). This allowed the rabbits to become used to tonometry and the tonometrist and assistants to become more practised with the Alcon pneumatonograph.

Almost all applications of the tonometer to the rabbits' eyes were done by one experienced tonometrist (TS); the extremely few exceptions were unavoidable. The right eye was invariably assessed first, the left second. Fifteen minutes was allowed for 
the pneumatonograph to warm up before each series of tonometries.

The 12 rabbits received twice weekly (on a Monday and Thursday, after all tonometries had been done for that day) a subconjunctival injection of $0.2 \mathrm{ml}$ of a $1 \%$ suspension of RU486 $(2 \mathrm{mg})$ in normal saline in one eye chosen at random; the other eye received a subconjunctival injection of the same volume of vehicle, namely normal saline only. Topical anaesthesia was obtained in all eyes by instillation of $0 \cdot 4 \%$ benoxinate oxybuprocaine $\mathrm{HC} 1$ eye drops just before the injections. Six rabbits received 'active' injections in right eyes and six in left eyes (fellow eyes having vehicle injections) to ensure that half of the actively treated eyes were tonometrised first and half of the vehicle treated eyes were tonometrised first (the right eye always being tonometrised first). That plan was used in order to avoid the possible 'contaminant' of a systematic difference in pressure between first- and second-tonometrised eyes.

Each tonometry reading was the average of three separate applications in quick succession of the pneumatonograph footplate to the cornea. Each of the three constituent pressures was read from the graph printout from the recording section of the pneumatonograph. A judgment was made of the pressure from the 5-second trace, which usually showed a gradually falling, irregular line; the judge (ST) was unbiased because he was unaware of which eye was the treated eye and which the control.

Tonometry was done twice daily, for six days per week, except for week V, which was of five days only.

Within 48 hours of the end of the series of tonometries done throughout the five treatment weeks a water loading test by intraperitoneal injections of sterile distilled water $(50 \mathrm{ml} / \mathrm{kg}$ body weight) was done on each rabbit, followed by tonometry at 15 -minute intervals for 1.5 hours. ${ }^{12}$

\section{Results}

The graphs in Fig. 1A, B show the mean tonometry for each of the 5 weeks, the first being pretreatment weeks and II to V being treatment weeks. Weeks I to IV were six-day weeks (Tuesday until following Monday), but week V was a five-day week (Tuesday to Saturday).

Table 1 shows that the mean reduction in pressure in the actively treated eye compared with the vehicletreated eye for weeks I (pretreatment), II, III, IV, and $\mathrm{V}$ was $-0.03,0.61,0.63,0.61$, and $0.81 \mathrm{mmHg}$ respectively. Although these figures are quite consistent, only the reductions in weeks IV and V were significant (the reduction in week IV at the rather weak $7 \%$ significance level), because of a higher variance in weeks II and III.
Pretreatment week I was available. $\mathrm{R}-\mathrm{L}$ or $\mathrm{L}-\mathrm{R}$ differences are recorded in row I of Table 1 depending on whether $\mathrm{R}$ or $\mathrm{L}$ eye was planned to be actively treated in weeks II to V. Subtraction of the differences (vehicle-treated minus RU486-treated) in weeks IV and V from the differences (R-L or L-R) in pretreatment week I removed possible systematic differences between the two eyes of each rabbit but resulted in non-significant Student's $t$ values (see lowest two rows of Table 1 ). We would attribute this to the higher variance in week $I$, which was a run-in week to habituate the rabbits to handling and tonometry. (Accordingly, such a week is often unsatisfactory as a base line 'control' week.)

Within 48 hours of the end of the series of tonometries the ocular hypertensive response to intraperitoneal injections of sterile distilled water was measured, but no intereye difference could be detected.

\section{Discussion}

The effect on IOP of subconjunctival injections of RU486, a peripheral corticosteroid blocking drug, is quantitatively very similar to that of eye drops which has already been reported, ${ }^{9}$ when the ocular tension also fell by about $0.75 \mathrm{mmHg}$. The initiating hypothesis in both series has been that one factor normally affecting (reducing) the facility of outflow of aqueous humour is the effect of normal tissue levels of corticosteroids. We have not yet been able to do clinical trials of eye drops which we expect would produce a greater fall in pressure in patients with or hereditarily predisposed to open-angle glaucoma, because their trabecular meshwork is probably more susceptible to normal tissue steroid levels than is the normal meshwork. The rabbit eye is by no means ideal for these studies but has the material advantage of inexpensive convenience, and also does respond to corticosteroid drops with a rise in pressure, albeit transient. ${ }^{1314}$

It was rather disappointing to find that the subconjunctival route may not be more effective than the route via eye drops, but we are cautious about overinterpreting intertrial similarities. A possible explanation may lie in the insolubility of RU486 in water. However, a plausible explanation is that the subconjunctival route merely constitutes a reservoir to supply a continuous stream of any drug through the puncture wound of the conjunctiva and over the cornea through which the drug is absorbed; an interesting paper by Wine et al..$^{15}$ provides good evidence for that mechanism of action. We could not accurately assess the depth of the injection; a subconjunctival level seems to achieve better penetration than a sub-Tenon's level. ${ }^{16} 17$ 

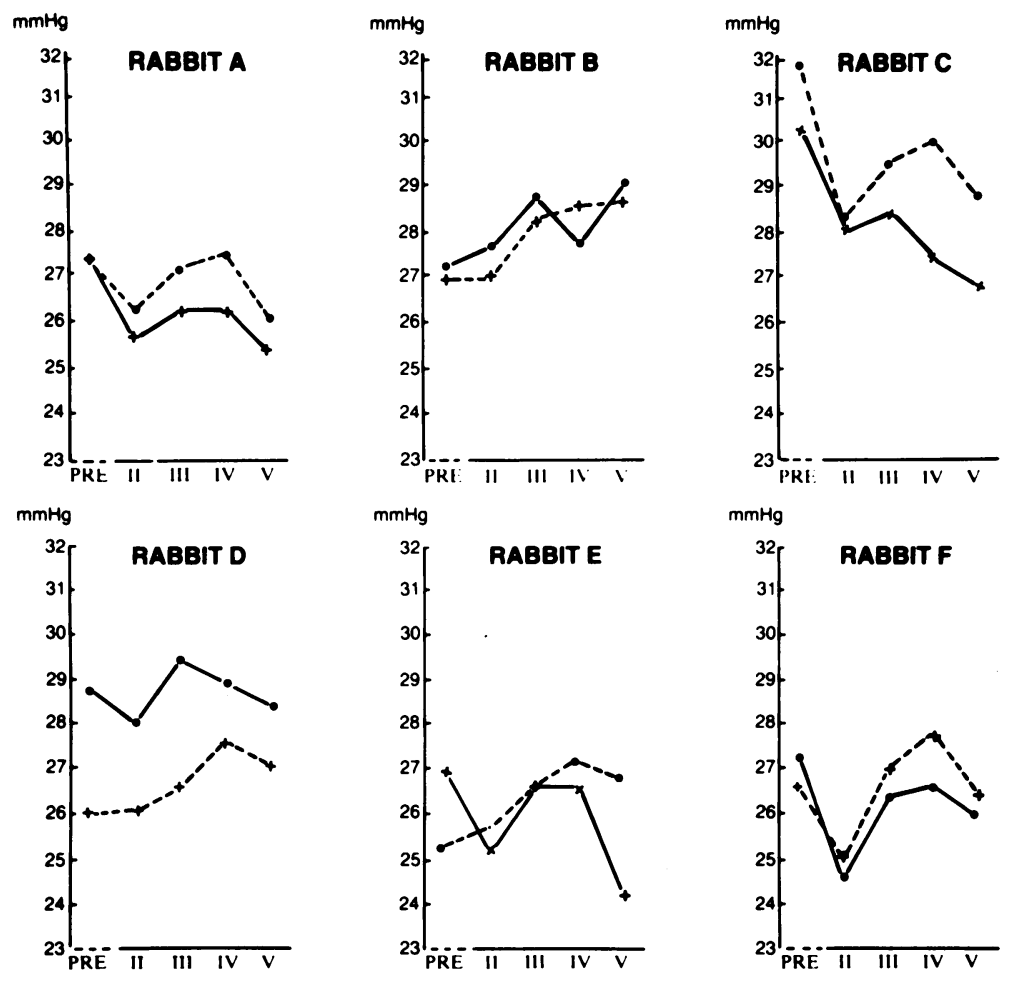

Fig. 1A
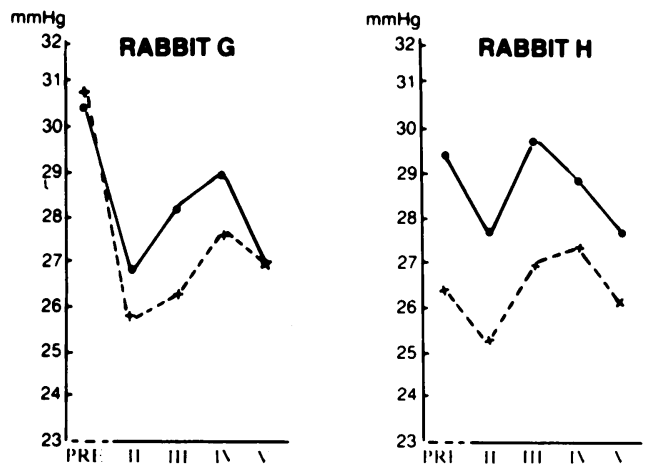

Fig. 1 Weekly mean of two daily tonometry readings for 12 rabbits given subconjunctival 2 mg of RU 486 as a $1 \%$ suspension in $0 \cdot 2 \mathrm{ml}$ saline to one eye $(+)$. The fellow eye received subconjunctival $0 \cdot 2 \mathrm{ml}$ of

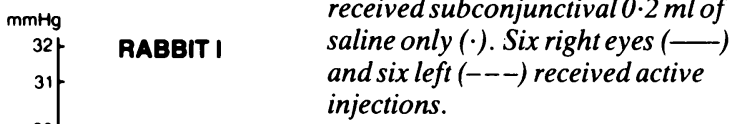


Table 1 Pneumatonograph readings on 12 rabbits treated with subconjunctival RU486 suspension in one eye, the fellow eye being treated with 'vehicle' subconjunctivally. For weeks I to $V$ the weekly totals of (vehicle minus RU486) differences are presented for each rabbit, with a column of mean differences per reading and per week. (Vehicle - RU486) means difference in pressure between vehicle treated (or placebo treated) and $R U 486$ treated. Row I shows the differences between $R-L$ or $L-R$ depending on which eye is to be treated in weeks II to $V$, while rows II to $V$ show differences between vehicle treated and actively treated eyes. Student's $t$ and $p$ values are placed in the end columns. Wilcoxon matched pairs signed ranks tests gave similar results in week $I V\left(R_{-}=1+4 \cdot 5+6 \cdot 5=12 p<0 \cdot 10, n=11\right.$ non-zero pairs $)$ and in week $V(5$ days $)\left(R_{-}=1+2 \cdot 5+4=7 \cdot 5\right.$, $p<0.05, n=11$ non-zero pairs).

\begin{tabular}{|c|c|c|c|c|c|c|c|c|c|c|c|c|c|c|c|c|}
\hline $\begin{array}{l}\text { Week } \\
\text { (6 days) }\end{array}$ & $\begin{array}{l}R a b b i \\
A\end{array}$ & it & $C$ & $D$ & $E$ & $F$ & $G$ & $H$ & $I$ & $J$ & $K$ & $L$ & $\begin{array}{l}\text { Mean diff. } \\
\text { (vehicle - } \\
\text { RU486) } \\
\text { per reading } \\
\mathrm{mmHg}\end{array}$ & $\begin{array}{l}\text { Mean diff. } \\
\text { (vehicles - } \\
\text { RU486) } \\
\text { per week } \\
\text { mmHg }\end{array}$ & $\begin{array}{l}\text { Student'st } \\
(n=I I)\end{array}$ & $\begin{array}{l}p \\
(N S=n o t \\
\text { significant })\end{array}$ \\
\hline $\begin{array}{l}\text { I } \\
\text { (Pretreat- } \\
\text { ment) }\end{array}$ & -4 & 11 & 51 & 97 & -58 & 18 & -14 & 107 & 10 & -79 & -48 & -92 & -0.03 & $-1 \cdot 0$ & & NS \\
\hline $\begin{array}{l}\text { II } \\
\text { III } \\
\text { IV } \\
\text { V (5 days) }\end{array}$ & $\begin{array}{l}23 \\
33 \\
45 \\
20\end{array}$ & $\begin{array}{r}26 \\
17 \\
-30 \\
12\end{array}$ & $\begin{array}{l}12 \\
41 \\
95 \\
60\end{array}$ & $\begin{array}{r}68 \\
104 \\
47 \\
38\end{array}$ & $\begin{array}{r}16 \\
0 \\
21 \\
83\end{array}$ & $\begin{array}{l}-13 \\
-22 \\
-43 \\
-16\end{array}$ & $\begin{array}{r}37 \\
67 \\
43 \\
0\end{array}$ & $\begin{array}{r}88 \\
102 \\
54 \\
43\end{array}$ & $\begin{array}{r}105 \\
32 \\
30 \\
49\end{array}$ & $\begin{array}{r}-18 \\
-81 \\
0 \\
-8\end{array}$ & $\begin{array}{r}-17 \\
11 \\
12 \\
21\end{array}$ & $\begin{array}{l}-63 \\
-31 \\
-10 \\
-12\end{array}$ & $\begin{array}{l}0.61 \\
0.63 \\
0.61 \\
0.81\end{array}$ & $\begin{array}{l}22 \\
22 \cdot 8 \\
22 \cdot 0 \\
24 \cdot 2\end{array}$ & $\begin{array}{l}1 \cdot 59 \\
1 \cdot 47 \\
1.96 \\
2 \cdot 69\end{array}$ & $\begin{array}{l}\text { NS } \\
\text { NS } \\
0.07 \\
0.025\end{array}$ \\
\hline $\begin{array}{l}\text { I-IV } \\
\text { I-V }\end{array}$ & $\begin{array}{l}-49 \\
-19\end{array}$ & $\begin{array}{r}41 \\
3\end{array}$ & $\begin{array}{r}-44 \\
-5\end{array}$ & $\begin{array}{l}50 \\
50\end{array}$ & $\begin{array}{r}-79 \\
-143\end{array}$ & $\begin{array}{l}61 \\
44\end{array}$ & $\begin{array}{l}-57 \\
-10\end{array}$ & $\begin{array}{l}53 \\
55\end{array}$ & $\begin{array}{l}-20 \\
-52\end{array}$ & $\begin{array}{l}-79 \\
-51\end{array}$ & $\begin{array}{l}-60 \\
-66\end{array}$ & $\begin{array}{l}-22 \\
-71\end{array}$ & & $\begin{array}{l}-22 \cdot 1 \\
-22 \cdot 1\end{array}$ & $\begin{array}{l}-1 \cdot 35 \\
-1 \cdot 31\end{array}$ & $\begin{array}{l}\text { NS } \\
\text { NS }\end{array}$ \\
\hline
\end{tabular}

It was surprising that intraperitoneal waterloading with distilled water did not show any intereye difference. We had expected it would be greater than the difference found during the five weeks of treatment.

Calibration of the pneumatonograph machine was done on several enucleated eyes of rabbits. Actual pressure was monitored by a pressure transducer and chart-recorded via a needle in the anterior chamber. The readings gave very similar estimates to those of the electronic pressure transducer (but see Hammond and Bhattachergee ${ }^{18}$ ).

Some contributions to variance came from lack of

Table 2 Summary of four experiments: mean (vehicle - RU486) difference per reading

\begin{tabular}{|c|c|c|c|c|c|c|}
\hline $\begin{array}{l}\text { Number of rabbits } \\
\text { Tonometer } \\
\text { RU-administration } \\
\text { Place }\end{array}$ & & $\begin{array}{l}12 \\
\text { Applanation } \\
\text { Eye drops } \\
\text { Edinburgh }\end{array}$ & $\begin{array}{l}12 \\
\text { PTG } \\
\text { Eye drops } \\
\text { Augusta } I^{10}\end{array}$ & $\begin{array}{l}6 \\
\text { PTG } \\
\text { Eye drops } \\
\text { Augusta II }\end{array}$ & $\begin{array}{l}12 \\
\text { PTG } \\
\text { Sub-conjunctival } \\
\text { injection } \\
\text { Yamanashi } \\
\text { (present paper) }\end{array}$ & Summed \\
\hline First treatment & Mean & $0 \cdot 24$ & $0 \cdot 22$ & 0.26 & $0: 62$ & $1 \cdot 34$ \\
\hline Second treatment & Mean & 0.66 & 1.06 & $0 \cdot 28$ & 0.70 & $2 \cdot 70$ \\
\hline Two weeks & Variance of mean & 0.0198 & $0 \cdot 1252$ & 0.0604 & 0.0759 & $\begin{aligned} & 0.2814 \\
z & =5.09 \\
p & <0.001\end{aligned}$ \\
\hline $\begin{array}{l}\text { Third treatment } \\
\text { two weeks }\end{array}$ & $\begin{array}{l}\text { Mean } \\
\text { Variance of mean } \\
n\end{array}$ & $\begin{array}{l}0.69 \\
0 \cdot 0261 \\
10^{*}\end{array}$ & $\begin{array}{l}0 \cdot 39 \\
0 \cdot 1342 \\
12\end{array}$ & $\begin{array}{l}0 \cdot 84 \\
0 \cdot 0136 \\
5\end{array}$ & - & $\begin{aligned} & 1.92 \\
& 0.1739 \\
z= & 4.84 \\
p< & 0.001\end{aligned}$ \\
\hline $\begin{array}{l}\text { Fourth treatment } \\
\text { two weeks }\end{array}$ & $\begin{array}{l}\text { Mean } \\
\text { Variance of mean } \\
\mathbf{n}\end{array}$ & $\begin{array}{l}1 \cdot 03 \\
0 \cdot 0158 \\
6^{*}\end{array}$ & $\begin{array}{l}0 \cdot 38 \\
0 \cdot 0546 \\
12\end{array}$ & - & - & $\begin{aligned} & 1.41 \\
& 0.0703 \\
z= & 5.32 \\
p< & 0.001\end{aligned}$ \\
\hline $\begin{array}{l}\text { Fifth treatment } \\
\text { two weeks }\end{array}$ & $\begin{array}{l}\text { Mean } \\
\text { Variance of mean } \\
n\end{array}$ & $\begin{array}{l}0 \cdot 46 \\
0 \cdot 0280 \\
12\end{array}$ & $\begin{array}{l}0 \cdot 06 \\
0 \cdot 1134 \\
12\end{array}$ & - & - & $\begin{aligned} & 0.52 \\
& 0.1414 \\
z= & 1.40\end{aligned}$ \\
\hline
\end{tabular}

* Incomplete: tonometrist's annual leave. 
docility at times in some animals, with consequent difficulty in achieving satisfactory readings. None of the starting rabbits was subsequently rejected. A better plan would be to screen a larger cohort of animals some of which could be excluded before randomisation during a longer run-in period of a few weeks; the study would then start with a valid base line control week just before the experimental weeks.

We consider that the lack of significant effect in weeks II and III may be attributable partly to high variance as much as to a possibly slow build up of effectivity of the drug (such as probably applies in steroid-induced glaucoma). Our previous study suggested a delay in effectivity. ${ }^{910}$

Any small difference between the response of the six slightly younger and lighter albino rabbits and the other six slightly older and heavier black and white rabbits would not allow valid conclusions about a difference in susceptibility, mainly because of paucity of numbers.

We take this opportunity to summarise our experience from four series of randomised rabbit experiments (see Table 2). For each posttreatment two weeks Table 2 shows the pooled $95 \%$ confidence interval for the mean difference (vehicle minus RU486) per reading of ocular tension (this assumes that the effect of the drug is the same in each trial). There is some suggestion in Table 2 of a lesser effect in the first treatment two weeks compared with the second, third, and fourth two weeks posttreatment.

Although the fall in pressure produced by RU486, a peripheral corticosteroid blocking drug, is small in rabbits, we expect a clinically useful effect in patients with or predisposed to open-angle glaucoma. Clinical trials are planned. The antiprogesterone properties of RU486 have already attracted clinical use in various situations." In the longer term two different sets of drugs will probably evolve, one with selective corticosteroid blocking properties and another with selective progesterone blocking attributes.

\section{References}

1 François J. Cortisone et tension oculaire. Ann Oçulist (Paris) 1954; 187: 805-16.

2 Becker B, Mills DW. Corticosteroids and intraocular pressure. Arch Ophthalmol 1963; 70: 500-7.

3 Armaly MF. Effect of corticosteroids on intraocular pressure and fluid dynamics. I. The effect of dexamethasone in the normal eye. Arch Ophthalmol 1963a; 70: 482-91.

4 Armaly MF. Effect of corticosteroids on intraocular pressure and fluid dynamics. II. Effect of dexamethasone in glaucomatous eyes. Arch Ophthalmol 1963b; 70: 492-9.

5 Becker B, Hahn KA. Topical corticosteroids and heredity in open-angle glaucoma. Am J Ophthalmol 1964; 57: 543-51.

6 Armaly MF. Statistical attributes of the steroid hypertensive response in the clinically normal eye. Invest Ophthalmol Vis Sci $1965 ; 4:$ 187-97.

7 Becker B. Intraocular pressure response to topical corticosteroids. Invest Ophthalmol Vis Sci 1965; 4: 198-205.

8 Armaly MF. Inheritance of dexamethasone hypertension and glaucoma. Arch Ophthalmol 1967; 77: 747-51.

9 Phillips CI, Green K, Gore SM, Cullen PM, Campbell M. Eye drops of RU486, a peripheral steroid blocker, lower intraocular pressure in rabbits. Lancet 1984 ; i: 767-8.

10 Green K, Phillips CI, Gore SM, Elijah RD, Bowman RA, Cullen PM. Ocular fluid dynamics response to topical RU486-6, a peripheral steroid blocker. Curr Eye Res 1985; 4: 605-12.

11 Healy DL, Fraser HM. The antiprogesterones are coming: menses induction, abortion and labour? $\mathrm{Br}$ Med J 1985; 290: $580-1$.

12 Flach AJ, Peterson JS, Seligmann KA. Local ocular hypotensive effect of topically applied acetazolamide. Am J Ophthalmol 1984; 98: 66-72.

13 Levene RZ, Rothberger M, Rosenberg S. Corticosteroid glaucoma in the rabbit. Am J Ophthalmol 1974; 78: 505-10.

14 Bonomi L, Perfetti S, Noya E, Bellucci R, Tomazzoli L. Experimental corticosteroid ocular hypertension in the rabbit. Graefes Arch Klin Exp Ophthalmol 1978; 209: 73-82.

15 Wine NA, Gornall AG, Basu PK. Ocular uptake of subconjunctivally injected $\mathrm{C}^{14}$ hydrocortisone. Am J Ophthalmol 1964; 58: $362-5$.

16 Hardy RG, Paterson CA. Ocular penetration of ${ }^{14} \mathrm{C}$-labelled chloramphenicol following subconjunctival or sub-Tenon's injection. Am J Ophthalmol 1971; 71: 1307-13.

17 Paterson CA. Intraocular penetration of ${ }^{14} \mathrm{C}$-labelled penicillin after sub-Tenon's or subconjunctival injection. Ann Ophthalmol 1973; 5: 171-4.

18 Hammond BR, Bhattachergee P. Calibration of the Alcon pneumatonograph and Perkins tonometer for use in rabbits and cats. Curr Eye Res 1984; 3: 1155-8.

Accepted for publication 17 October 1985. 